\title{
PENGARUH PEMBELAJARAN ICI TERHADAP KEMAMPUAN REPRESENTASI MATEMATIS SISWA DITINJAU DARI GAYA KOGNITIF
}

\author{
Deviana $^{1 \S}$, I Nym Bagus Pramartha ${ }^{2}$ \\ ${ }^{1}$ ITB STIKOM BALI [Email deviana@ @stikom-bali.ac.id] \\ ${ }^{2}$ ITB STIKOM BALI [Email: baguspramartha@yahoo.co.id] \\ ${ }^{\S}$ Corresponding Author
}

\begin{abstract}
The purpose of this research is to find out : (1) the effect ICI model for attitude and ability of mathematical representation in terms of student's cognitive (2) how the model of learning ICI can affect the attitude and the ability of mathematical representation in terms of students' cognitive. The research type is a combination of research using concurrent embedded design with mixed methods. Then, quantitative methods use post test design only control group design and analyzed using MANCOVA while qualitative method using descriptive research with data reduction, data presentation and verification. The results showed that: (1) learning with the ICI Model has a positive effect on Attitude and Ability of Mathematical Representation Viewed From Student Cognitive Styles on Line and Corner Material Class $(\lambda=30.319, p>0.05)$, (2) Students with FI cognitive style tend to have fulfilled three components of attitude and stages of mathematical representation; students with cognitive style field dependent tend not to be able to show attitude that refers to the three components of mathematical attitudes and have been able to understand the problems but in representing less and not yet able to complete the solution of the problems given.
\end{abstract}

Keywords: mathematical representation, cognitive styles, ICI

\section{PENDAHULUAN}

Dalam kegiatan pembelajaran, siswa berperan sebagai subjek dan objek dari kegiatan pembelajaran di kelas. Tujuan pembelajaran dapat dilihat dari hasil belajar yang diperoleh siswa setelah proses pembelajaran selesai melalui beberapa tes. Dalam menempuh hasil belajar terdapat banyak permasalahan yang mempengaruhi siswa selama proses pembelajaran salah satunya yaitu faktor internal pada siswa dalam merespon suatu aktivitas pada proses pembelajaran. Faktor internal dalam menanggapi suatu aktivitas salah satunya adalah sikap. Sikap siswa dalam proses belajar menggambarkan penampilan siswa di kelas, sikap siswa juga dapat terlihat dari kemauan, tanggapan, perubahan perasaan dan lain-lain. Banyak kita temukan berbagai sikap siswa selama proses belajar yaitu siswa yang aktif dan siswa yang bersikap pasif.

Sejalan dengan NCTM (2003) menyatakan, dalam belajar matematika siswa dituntut untuk memiliki kemampuan pemahaman, pemecahan masalah, komunikasi, koneksi matematika dan mempresentasikan ide-ide. Sejalan dari tujuan tersebut jelaslah bahwa kemampuan representasi matematis merupakan kemampuan yang penting untuk dikembangkan di sekolah. Kemampuan representasi matematis adalah kemampuan yang berkaitan dengan kemampuan terhadap pemahaman konsep. Fokus utama dalam mengkonstruksi pemahaman dan pengetahuan siswa dalam memahami suatu konsep matematika merupakan bagian penting dari representasi. Sejalan dengan Wahyudin (2012), representasi itu dilakukan dalam mendukung pemahaman para siswa antar berbagai konsep matematis yang berkaitan dalam menerapkan konsep matematika pada situasi-situasi permasalahan realistik lewat pemodelan. Sejalan dengan hal tersebut, Lestari (2012) mengemukakan bahwa salah satu cara terbaik membantu siswa memahami matematika adalah melalui representasi matematis yaitu dengan mendorong siswa menemukan atau membuat representasi sebagai alat berpikir dalam 
mengkomunikasikan gagasan matematika. Siswa dapat mempresentasikannya ke dalam berbagai macam cara, dengan menggunakan objek-objek nyata ,baik berupa tulisan, symbol ataupun gambar. Hal yang menunjukkan masih rendahnya kemampuan representasi matematis siswa yaitu menurut Hutagol (2013) kurang berkembangnya daya representasi siswa khususnya siswa sekolah menengah pertama karena siswa tidak pernah diberi kesempatan untuk melakukan representasi sendiri, tetapi harus mengikuti apa yang dicontohkan oleh guru. Hasil studi Hudiono (2005) menunjukan bahwa terjadinya kelemahan kemampuan representasi siswa karena penyajian materi dalam bentuk tabel, gambar, model hanya digunakan sebagai pelengkap dalam menyampaikan materi. Sebagai upaya dalam meningkatkan kemampuan representasi matematis siswa dan sikap maka diperlukan metode pembelajaran inovatif sehingga siswa diberikan kesempatan untuk melakukan representasi sendiri.

Berdasarkan permasalahan yang telah diungkapkan maka diperlukan pembelajaran yang dapat memfasilitasi siswa untuk bersikap aktif, menarik dan menarik minat siswa untuk berpikir dan berinteraksi dengan lingkungannya sehingga berpengaruh terhadap kemampuan siswa dalam representasi matematis dan memahami materi saat pembelajaran berlangsung. Salah satu model pembelajaran yang sesuai dengan permasalahan diatas adalah ICI. Siswa diharapkan akan memiliki pola berpikir konstruktivis, dapat menghubungkan pengetahuan awal mereka dengan temuantemuan dalam proses pembelajaran, lalu dapat melatih siswa dalam kebiasaan berpikir kritis dan kreatif, meningkatkan kerjasama antar anggota kelompok sehingga akan meningkatkan pemahamannya terhadap konsep yang diajarkan melalui interaksi antara guru dengan siswa, dengan temannya dan dengan materi yang diajarkan serta dapat menimbulkan situasi belajar aktif.

Selain model pembelajaran yang digunakan, karakteristik siswa juga mempengaruhi kualitas hasil pembelajaran. Siswa memiliki karakteristik yang berbedabeda, sehingga cara seseorang dalam berpikir memiliki cara-cara yang berbeda atas pengalaman yang dilakukannya terhadap situasi belajar, cara mereka menerima pembelajaran, mengorganisasikan, serta menghubungkan pengalaman-pengalaman mereka dalam cara mereka merespon terhadap metode pembelajaran. Salah satu yang terkait dengan karakteristik yang mempengaruhi adalah gaya kognitif.

Gaya kognitif merupakan bagaimana cara cara siswa menerima dan mengelola sikap terhadap informasi yang diperoleh, maupun kebiasaan yang berkaitan dengan belajar. Salah satu dimensi gaya kognitif yang secara khusus perlu dipertimbangkan dalam pendidikan adalah gaya kognitif yang dibedakan berdasarkan perbedaan psikologis yakni gaya kognitif. Menurut Yahya (2005) gaya kognitif tersenut dibedakan menjadi dua, fieldindependent dan field-dependent. Siswa dengan gaya kognitif field-independent cenderung memilih belajar individual, menanggapi dengan baik, dan bebas (tidak tergantung pada orang lain). Mereka dapat mencapai tujuan dengan motivasi intrinsik, dan cenderung bekerja untuk memenuhi tujuan sendiri. Sedangkan siswa yang memiliki gaya kognitif field-dependent lebih memilih belajar berkelompok dan sesering mungkin berinteraksi dengan guru, untuk mendapatkan penguatan yang bersifat ekstrinsik.

Mengingat gaya kognitif siswa berbedabeda, maka seorang pendidik perlu menyesuaikan pembelajaran dengan gaya kognitif dari siswa tersebut. Penyesuaian tersebut diharapkan dapat membuat siswa lebih paham dalam memproses atau mengorganisasikan informasi yang dibelajarkan guru maupun konsep yang didapat dari pengalaman siswa itu sendiri. Penerapan model pembelajaran yang sesuai dengan karakteristik siswa diharapkan dapat memberikan kesempatan kepada siswa secara aktif dalam proses pembelajaran matematika baik itu dalam menemukan konsep yang tepat, merepresentasikan sesuai dengan konsep yang dimiliki siswa dari pengalamannya.

Berdasarkan uraian di atas, peneliti termotivasi untuk melakukan penelitian tertarik untuk mengetahui Pengaruh Model Pembelajaran ICI Terhadap Sikap dan Kemampuan Representasi Matematis Ditinjau Dari Gaya Kognitif Siswa Pada Materi Garis dan Sudut. Penelitian ini bertujuan untuk mengetahui pengaruh model pembelajaran ICI (Interactive Conceptual Intruction) terhadap sikap dan kemampuan representasi matematis ditinjau dari gaya kognitif siswa pada materi garis dan sudut. 


\section{METODE PENELITIAN}

Penelitian yang digunakan adalah penelitian kombinasi dengan menggunakan concurrent embedded design mixed methods (campuran tidak berimbang) (Candiasa, 2010). Metode primer yang digunakan dalam penelitian ini adalah metode kuantitatif dan metode sekunderyang digunakan adalah metode kualitatif. Penelitian kuantitatif menggunakan rancangan The Randomized Posttest Only Control Group Design (Sugiyono, 2012). Sedangkan penelitian kualitatifnya menggunakan penelitian deskriptif. Populasi dalam penelitian ini adalah siswa salah satu sekolah menengah pertama kelas VII 307 siswa.

Adapun langkah setelah menentukan populasi adalah menentukan pengambilan sampel dan dilanjutkan dengan uji kesetaraan terhadap sampel.. Pengambilan sampel untuk kuantitatif pada penelitian ini mengunakan cluster random sampling yang dilakukan dengan pengundian sehingga diperoleh dua kelas dan diundi kembali yang menjadikan kelas VII F yang berjumlah 34 siswa sebagai kelas eksperimen dan VII I yang berjumlah 35 siswa sebagai kelas kontrol. Untuk data kualitatifnya penentuan sampel menggunakan teknik purposive sampling dengan criteria memiliki kecenderungan terkuat dari masingmasing gaya kognitif field dependent dan field independent. Penentuan sampel menggunakan instrumen tes GEFT (Group Embedded Figure Test). Pengisisan instrumen GEFT dilakukan di kelas eksperimen yaitu pada siswa kelas VIIF. Dari hasil test GEFT, diperoleh 2 siswa dengan skor test GEFT mendekati 0 yaitu S1 dengan skor 7 dan S2 dengan skor 5. Kedua subjek tersebut merupakan subjek yang memiliki kecenderungan terkuat pada gaya kognitif FD. Selain itu, dari hasil test GEFT diperoleh 2 siswa dengan skor test GEFT mendekati 18 yaitu T1 dengan skor 17 dan T2 dengan skor 16 kedua subjek tersebut merupakan subjek yang memiliki kecenderungan terkuat pada gaya kognitif FI. Data dalam penelititan ini dikumpulkan dengan tes kemampuan pemecahan masalah matematika dan angket sikap siswa.

Adapun materi ajar yang dipilih dalam penelitian ini adalah materi garis dan sudut. Variabel bebas dari penelitian ini adalah Model pembelajaran ICI yang diterapkan pada kelas eksperimen dan Strategi Pembelajaran
Konvensional pada kelas kontrol. Varibel terikat dari penelitian ini adalah sikap siswa dan kemampuan representasi matematis siswa. Sedangkan variabel konkomitannya adalah gaya kognitif.

Penelitian ini menggunakan dua instrumen yaitu (1) angket sikap siswa, dan (2) tes kemampuan representasi matematis siswa. Sebelum digunakan dalam penelitian, instrument penelitian terlebih dahulu di uji coba. Analisis yang digunakan dalam pengujian instrument angket sikap siswa dan tes kemampuan representasi matematis siswa adalah uji validitas dan reliabilitas tes.

Analisis data kuantitatif dilakukan dengan MANCOVA. Sebelum data dianalisis, terlebih dahulu dilakukan uji prasyarat berupa uji normalitas multivariate, uji homogenitas matriks varian/kovarian, uji linearitas antara variabel terikat dengan variabel konkomitan dan uji kesejajaran koefisien regresi. Analisis data kualitatifnya dengan reduksi data, penyajian data, dan verifikasi data.

Hipotesis statistik yang akan diuji adalah sebagai berikut:

$\mathrm{H}_{0}$ (Hipotesis Nol): tidak adanya pengaruh pembelajaran ICI terhadap kemampuan representasi matematis siswa ditinjau dari gaya kognitif , melawan

$\mathrm{Ha}$ (Hipotesis Alternatif): adanya pengaruh pembelajaran ICI terhadap kemampuan representasi matematis siswa ditinjau dari gaya kognitif. Kriteria pengujian jika angka signifikan yang dihasilkan kurang dari 0.05 , hipotesis nol ditolak dan hipotesis alternatif diterima.

\section{HASIL DAN PEMBAHASAN}

Data kuantitatif yang dikumpulkan dalam penelitian ini yaitu data mengenai sikap siswa dan kemampuan representasi matematis siswa sebagai hasil perlakuan dari pengaruh penerapan Model pembelajaran ICI (Interactive Conceptual Intruction) dan pembelajaran konvensional.

Tabel 1. Rekaptulasi Data Hasil Perhitungan Deskriptif

\begin{tabular}{|l|l|l|l|l|}
\hline Statistik & \multicolumn{1}{|c|}{$\mathrm{A}_{1} \mathrm{Y}_{1}$} & \multicolumn{1}{|c|}{$\mathrm{A}_{2} \mathrm{Y}_{1}$} & $\mathrm{~A}_{1} \mathrm{Y}_{2}$ & $\mathrm{~A}_{2} \mathrm{Y}_{2}$ \\
\hline$n$ & 34 & 35 & 34 & 35 \\
\hline Mean & 52.26 & 72.38 & 64.94 & 71.12 \\
\hline SD & 10.97 & 12.32 & 5.69 & 7.60 \\
\hline Var & 120.37 & 151.94 & 32.35 & 57.8 \\
\hline Max & 80 & 100 & 76 & 85 \\
\hline Min & 40 & 55 & 54 & 58 \\
\hline
\end{tabular}


Keterangan:

$\mathrm{A}_{1} \mathrm{Y}_{1}$ : Kemampuan Representasi Matematis siswa dengan model pembelajaran ICI

$\mathrm{A}_{2} \mathrm{Y}_{1}$ : Kemampuan Representasi Matematis siswa dengan kelas kovensional

$\mathrm{A}_{1} \mathrm{Y}_{2}$ : Gaya Kognitif siswa dengan model pembelajaran ICI

$\mathrm{A}_{2} \mathrm{Y}_{2}$ : Gaya Kognitif siswa dengan kelas konvensional

Sebelum data dianalisis, terlebih dahulu dilakukan uji prasyarat berupa uji normalitas multivariate, uji homogenitas matriks varian/kovarian, uji linearitas antara variabel terikat dengan variabel konkomitan dan uji kesejajaran koefisien regresi, dan uji normalitas multivariate dengan menggunakan scatter plot antara jarak mahalanobis dengan chi-square. Dari hasil analisis, tampak bahwa scatter plot cenderung membentuk garis lurus dan besar koefisien korelasi $>\mathrm{r}$ tabel atau nilai sig. $<0,05$ maka terdapat korelasi yang signifikan ini berarti sampel berdistribusi normal multivariate. Dengan demikian dapat dinyatakan bahwa data kemampuan representasi matematis dan sikap siswa berdistribusi normal. Uji Homogenitas matriks varian kovarian dilakukan dengan uji Box's $M$ didapat nilai signifikansinya adalah 0.355 lebih besar dari 5\% dengan demikian matriks varian/ kovarian dari variabel dependen adalah sama (homogen). Uji linearitas antara variabel terikat dengan variabel konkomitan dilakukan dengan tabel anova, diperoleh nilai linearitas antara kemampuan representasi matematis dengan gaya kognitif sebesar 59.852 dengan nilai signifikasi sebesar 0.00 lebih kecil dari 0.05 dengan dengan demikian $\mathrm{H}_{0}$ ditolak jadi gaya kognitif mempengaruh (berpengaruh secara linear) kemampuan representasi matematis dan nilai linearitas antara sikap dan gaya kognitif sebesar 5.353 dengan nilai signifikan sebesar 0.024 lebih kecil dari 0.05 dengan demikian $\mathrm{H}_{0}$ ditolak jadi gaya kognitif mempengaruhi (berpengaruh secara linear) sikap. Uji kesejajaran koefisien regresi dilakukan dengan bantuan spss dengan nilai 0.816 dengan nilai signifikan 0.447 karena nilai signifikan lebih kecil dari 0.05 maka $\mathrm{H}_{0}$ diterima. Dengan demikian regresi kedua kelompok sejajar.

Berdasarkan hasil uji prasyarat dapat disimpulkan bahwa data dari semua kelompok berdistribusi normal dan homogen. Oleh sebab itu, uji hipotesis dengan MANCOVA dapat dilanjutkan. Berdasarkan hasil analisis uji
Pillai's Trace, Wilk's Lambda, Hotteling's Trace, Ray's Largest Root menunjukkan F hitung sebesar 30.319 dan memiliki signifikansi sebesar 0,00 (0.00 dibagi 2 untuk hipotesis satu arah) kurang dari 0,05. Hal ini berarti harga $F$ untuk Pillai's Trace, Wilk's Lambda, Hotteling's Trace, Ray's Largest Root semuanya signifikan. Jadi secara simultan model pembelajaran ICI (Interactive Conceptual Intruction) berpengaruh positif terhadap kemampuan representasi matematis dan sikap siswa ditinjau dari gaya kognitif dengan siswa yang mengikuti model pembelajaran konvensional.

Demikian pula dengan hasil dari dari test of between-subjects effects menunjukkan, nilai $\mathrm{F}$ hitung dari kemampuan matematis adalah 31.788 dengan nilai signifikan dari kemampuan representasi matematis sebesar 0.00 (0.00 dibagi 2 untuk hipotesis satu arah), nilai ini lebih kecil dari alpha 0.05 dengan demikian $\mathrm{H}_{0}$ dapat ditolak, jadi model pembelajaran ICI (Interactive Conceptual Intruction) berpengaruh posisitif terhadap kemampuan representasi matematis siswa ditinjau dari gaya kognitif dengan siswa yang mengikuti model pembelajaran konvensional. Sedangkan hasil hubungan model pembelajaran ICI dengan sikap menunjukkan, nilai $\mathrm{F}$ hitung 12.555 dengan nilai signifikan dari sikap sebesar 0.001, nilai ini lebih kecil dari alpha 0.05 dengan demikian $\mathrm{H}_{0}$ ditolak, jadi model pembelajaran ICI (Interactive Conceptual Intruction) berpengaruh positif terhadap sikap siswa ditinjau dari gaya kognitif dengan siswa yang mengikuti model pembelajaran konvensional.

Berdasarkan hasil statistik deskriptif bahwa rata-rata skor sikap siswa pada kelompok yang mengikuti model pembelajaran ICI adalah 71.12 lebih tinggi dibandingkan rata-rata kelompok siswa dengan model konvensional yaitu 64.94 dengan kata lain, bahwa model pembelajaran ICI lebih unggul dibandingkan dengan model pembelajaran konvensional dalam pencapain sikap. Untuk rata-rata skor representasi matematis siswa dengan model pembelajaran ICI adalah 72.38 dan rata-rata skor representasi matematis siswa dengan model konvensional adalah 58.26, dengan kata lain model pembelajaran ICI lebih unggul dibandingkan dengan model pembelajaran konvensional dalam kemampuan representasi matematis. 
Selanjutnya data kualitatif didapat melalui observasi, dokumenter, kuesioner dan wawancara. Berdasarkan hasil analisis pada data kualitatif dapat diketahui bahwa siswa yang memiliki gaya kognitif FI pada kelas eksperimen setelah dibelajarkan dengan model ICI cenderung menunjukkan sikap ingin tahu yang tinggi, aktif di dalam kelas, cepat paham mengenai konsep materi garis dan sudut. Melalui pembelajaran dengan model ICI siswa yang memiliki gaya kognitif FI menyatakan dirinya bersemangat dan juga tertarik untuk bersama-sama menyelesaikan permasalahan yang diberikan sehingga dirinya dapat memahami konsep-konsep matematika karena pembelajaran di kelas mengkaitkan dengan kehidupan sehari-hari. Oleh karena itu belajar dapat semakin bermakna dan dapat diperluas ketika siswa menemukan permasalahan yang menggunakan konsep tersebut. Selain itu mereka juga menyatakan bahwa matematika sangat bermanfaat dalam kehidupan sehari-hari. Hal tersebut sesuai dengan kutipan wawancara salah satu seorang siswa: "ya pastilah banyak manfaatnya bu. Misalnya dalam kegiatan jual beli pasti perlu banget mempelajari matematika...matematika juga mampu melatih diri saya untuk teliti dalam mengerjakan sesuatu”. Dengan demikian siswa yang memiliki gaya kognitif FI telah mampu memenuhi tiga komponen sikap dalam pembelajaran matematika yaitu komponen kognisi, afeksi dan konaksi.

Demikian pula dalam hal representasi matematika, siswa yang memiliki gaya kognitif FI cenderung mampu menerapkan tahapan representasi yaitu menyajikan kembali data atau informasi dari suatu representasi ke representasi diagram, grafik, tabel atau gambar, menyelesaikan masalah dengan ekspresi matematika, dan membuat situasi maslah berdasarkan data atau representasi yang diberikan. Melalui model pembelajaran ICI siswa yang memiliki gaya kognitif FI mampu mengembangkan kemampuan pemahaman konsep dengan cara merepresentasikan idenya dengan memaknai permasalahan dan mengubahnya dalam bentuk gambar, simbul, maupun ekspresi matematis sehingga memudahkan siswa dalam memahami masalah. Sehingga melalui model pembelajaran ICI yang memiliki gaya kognitif FI telah mampu melakukan tahapan representasi. Mereka selalu ingin berusaha sendiri mencari jawaban atas suatu pertanyaan yang belum mereka temukan karena rasa ingin tahu yang sangat kuat.

Berdasarkan hasil pengamatan peneliti, siswa yang memiliki gaya kognitif FD cenderung menunjukkan sikap yang kurang aktif dan menyatakan matematika itu rumit terlalu banyak rumusnya. Hal tersebut peneliti simpulkan berdasarkan kutipan wawancara salah satu siswa yaitu "matematika itu membingungkan buk banyak rumusnya yang mana dipakai saya bingung jadinya saya males belajar matik". Berdasarkan pengamatan pebeliti, siswa yang memiliki gaya kognitif FD cepat sekali putus asa tidak mau berusaha ketika diberikan permasalahan. Sehingga siswa yang memiliki gaya kognitif FD belum mampu memenuhi komponen-komponen sikap dalam pembelajaran. Dalam representsi matematika siswa yang memiliki gaya kognitif FD masih sulit dalam menyatakan ide-idenya dan sulit mengubah masalah matematika ke dalam symbol matematika sehingga siswa yang memiliki gaya kognitif FD sulit merepresentasikan masalah yang diberikan.

\section{KESIMPULAN DAN SARAN}

Dari deskripsi umum hasil penelitian, pengujian hipotesis, dan pembahasan, dapat diberikan kesimpulan sebagai berikut.

1. Pembelajaran dengan penerapan model pembelajaran ICI berpengaruh positif terhadap sikap dan kemampuan representasi matematis ditinjau dari gaya kognitif siswa pada materi garis dan sudut. Ini ditunjukkan dengan lebih tingginya skor rata-rata sikap dan kemampuan representasi matematis siswa yang mengikuti pembelajaran dengan penerapan model pembelajaran ICI dibandingkan kelompok siswa yang mengikuti pembelajaran konvensional yang dilihat dari nilai ratarata angket sikap siswa dan test kemampuan representasi matematis siswa.

2. Siswa yang memiliki gaya kognitif FI pada kelas eksperimen cenderung telah memenuhi tiga komponen sikap dan telah memenuhi tahapan dalam proses representasi matematis; siswa yang memiliki gaya kognitif FD cenderung belum mampu menunjukkan sikap yang mengacu pada tiga komponen sikap matematika dan telah mampu memahami permasalahan tapi dalam merepresentasikan ke dalam representasi gambar kurang tepat karena apa yang di 
gambar dan apa yang dijelaskan tidak sesuai. Serta belum mampu dengan tuntas melakukan penyelesaian permasalahan yang diberikan.

\section{DAFTAR PUSTAKA}

Candiasa, I M,.2010. Statistik Univariat Dan Bivariat Disertai Aplikasi SPSS. Singaraja: Universitas Pendidikan Ganesha.

Hudiono. 2005. Meningkatkan Kemampuan Representasi dan Pemecahan Masalah Siswa SMA Melalui Model Pembelajaran Mathematics Project. Skripsi FPMIPA UPI Bandung: tidak diterbitkan.

Lestari, H. 2012. Efektivitas Penerapan Pembelajaran Kooperatif Tipe Modified Jigsaw untuk Meningkatkan Kemampuan Representasi Matematis Siswa. [Online] Tersedia.

Hutagaol, K..2013. Pembelajaran Kontekstual Untuk Meningkatkan Kemampuan Representasi Matematis Siswa Sekolah Menengah Pertama. Infinity Journal, 2(1), 85-99.

NCTM.2003. Standards for Secondary Mathematics Teacher. United States of America: The National Council of Teachers of Mathematics, Inc.

Sugiyono. 2012. Metode Penelitian Kuantitatif, Kualitatif, dan Kombinasi (Mixed Methods). Bandung: Alfabeta.

Wahyudin. 2012. Filsafat dan model-model pembelajaran matematika (pelengkap untuk meningkatkan kompetensi pedagogis para guru dan calon guru profesional). Bandung : Penerbit Mandiri.

Yahya, Azizi. dkk. 2005. Aplikasi Kognitif dalam Pendidikan. Pahang: Proffesional Publishing. 